\title{
Molecular characterization of soybean cultivars by microsatellite markers with universal tail sequence
}

\author{
Carlos Alexandre Gomes Ribeiro(1), Janaína Paula Marques Tanure ${ }^{(2)}$, \\ Talles Eduardo Ferreira Maciel(1) and Everaldo Gonçalves de Barros ${ }^{(1)}$
}

\begin{abstract}
(1)Universidade Federal de Viçosa, Instituto de Biotecnologia Aplicada à Agropecuária, CEP 36570-000 Viçosa, MG, Brazil. E-mail: carlosbiotec@yahoo.com.br, tallesmaciel@gmail.com, ebarros@ufv.br (2)Embrapa Gado de Corte, Avenida Rádio Maia, no 830, Vila Popular, Caixa Postal 154, CEP 79106-550 Campo Grande, MS, Brazil. E-mail: janaina.tanure@embrapa.br
\end{abstract}

\begin{abstract}
The objective of this work was to standardize a semiautomated method for genotyping soybean, based on universal tail sequence primers (UTSP), and to compare it with the conventional genotyping method that uses electrophoresis in polyacrylamide gels. Thirty soybean cultivars were genotypically characterized by both methods, using 13 microsatellite loci. For the UTSP method, the number of alleles (NA) was 50 (2-7 per marker) and the polymorphic information content (PIC) ranged from 0.40 to 0.74 . For the conventional method, the NA was 38 (2-5 per marker) and the PIC varied from 0.39 to 0.67 . The genetic dissimilarity matrices obtained by the two methods were highly correlated with each other $(0.8026)$, and the formed groups were coherent with the phenotypic data used for varietal registration. The 13 markers allowed the distinction of all analyzed cultivars. The low cost of the UTSP method, associated with its high accuracy, makes it ideal for the characterization of soybean cultivars and for the determination of genetic purity.

Index terms: Glycine max, cultivar protection, genetic diversity, genotyping method, random identity probability.

\section{Caracterização molecular de cultivares de soja por meio de marcadores microssatélites com sequência de cauda universal}

Resumo - O objetivo deste trabalho foi padronizar um método semi-automatizado para genotipagem de soja, baseado na metodologia de iniciadores com sequências de cauda universal (PSCU), e compará-lo ao método de genotipagem convencional de eletroforese em gel de poliacrilamida. Trinta cultivares de soja foram caracterizadas genotipicamente por ambos os métodos, com o uso de 13 locos microssatélites. Para o método PSCU, o número de alelos (NA) foi de 50 (2-7 por marcador) e o conteúdo de informação polimórfica (PIC) variou de 0,40 a 0,74 . Para o método convencional, o NA foi de 38 (2-5 por marcador) e o PIC variou de 0,39 a 0,67 . As matrizes de dissimilaridade genética obtidas pelos dois métodos apresentaram alta correlação entre si $(0,8026)$, e os grupos formados foram coerentes com dados fenotípicos utilizados para o registro varietal. Os 13 marcadores permitiram a distinção de todas as cultivares analisadas. O baixo custo do método PSCU, associado a sua alta acurácia, torna-o ideal para a caracterização de cultivares de soja e a determinação de pureza genética.
\end{abstract}

Termos para indexação: Glycine max, proteção de cultivar, diversidade genética, método de genotipagem, probabilidade de identidade ao acaso.

\section{Introduction}

Soybean [Glycine max (L.) Merr.] has been the fastest growing crop in Brazil for the last three decades and accounts for $52 \%$ of the cultivated area of the country (Companhia Nacional de Abastecimento, 2013). More than 1,000 varieties of soybean are registered in the National Cultivar Registration Service, and more than 590 cultivars are protected by the National Cultivar Protection Service (Brasil, 2013).

Distinguishability analysis is a basic requirement for DUS tests (distinguishability, uniformity and stability) used for cultivar protection. In the case of soybean, these tests have been hampered by the high phenotypic similarity among cultivars, which is mainly due to the narrow genetic base of cultivated genotypes (Priolli et al., 2004).

Molecular descriptors have been used for cultivar protection purposes by the United States Department of Agriculture (USDA) (Diwan \& Cregan, 1997). In Brazil, the molecular analysis is not yet recognized as an official method to aid the cultivar protection process, which is still based on phenotypic characteristics. 
Microsatellite markers are widely used for the determination of genetic diversity, paternity tests, varietal purity analysis, and genetic mapping (Schuster et al., 2004; Song et al., 2004; Garcia et al., 2007; Rodrigues et al., 2008; Oliveira et al., 2010; Kalia et al., 2011). With the advent of automatic techniques for genotyping, the use of fluorescent primers for DNA fragment analysis has become quite common (Lazaruk et al., 1998). Although this technique is remarkably practical, synthesis of fluorescently labeled primers is still an expensive step when compared to the synthesis of unlabeled ones (Hayden et al., 2008; Arruda et al., 2010).

Variations of the automated technique for microsatellite genotyping have been developed in order to match the speed and automation of the process with the quality and low cost of the analysis. Among them is a method first described by Oetting et al. (1995), which involves the joint use of three primers (unlabeled forward and reverse primers, and a fluorescently labeled M13 primer). This technique was first described in studies to evaluate genotypes in humans (Oetting et al., 1995). It was also used for genotyping animals (Diniz et al., 2007; Arruda et al., 2010) and several plant species, such as common beans (Oblessuc et al., 2009), rice (Goulart et al., 2011), apricot, cherry, barley, wheat (Hayden et al., 2008), Eucalyptus (Missiaggia \& Grattapaglia, 2006), and soybean (Priolli et al., 2010).

Based on Oetting et al. (1995), the universal tail sequence primers (UTSP) technique is proposed for the distinguishability of soybean cultivars using the fluorescently labeled universal primers M13, T3, and T7. In general, these primers do not match sequences present in plant genomes; therefore, they can be used for different plant species. Only three primers are fluorescently labeled. There is no need to label specific primers for each species to be analyzed. This is a great advantage if the high prices of fluorescently labeled primers are considered (Missiaggia \& Grattapaglia, 2006).

The objective of this work was to standardize a semiautomated method for genotyping soybean, based on UTSP, and to compare it with the conventional genotyping method that uses electrophoresis in polyacrylamide gels.

\section{Materials and Methods}

Thirty soybean cultivars, developed by different public and private institutions, were used: BMX Magna
RR; BRS 133; BRS 184; BRS 213; BRS 214; BRS 255RR; BRS 256RR; BRS 262; BRS 270RR; BRS Charrua RR; BRS Gisele RR; BRSMG 850GRR; BRS Pampa RR; BRSMT Pintado; BRS Valiosa RR; CD 202; CD 206; CD 213RR; CD 214RR; CD 215; CD 217; CD 219RR; CD 226RR; CD 228; CD 229RR; CD 237RR; CD 240RR; MG/BR 46 Conquista; M-SOY 7501; and Vmax (NK 7059 RR). Their germplasm were obtained from the Active Germplasm Bank of Embrapa Soja, Londrina, PR, Brazil, and from the seed companies Brasmax, Coodetec, Monsanto, and Syngenta. The genomic DNA was extracted according to Marcelino et al. (2008), using a bulk of 50 seeds for each cultivar. Information concerning the genealogy of the cultivars was obtained from the website CultivarWeb (Brasil, 2013).

For the UTSP method, a multiplex system was used, as described by Oetting et al. (1995), which included three kinds of primers: 1 , a sense microsatellite primer, which carries, besides its specific sequence, a 17 base pair (bp) tail at its 5' end identical to sequences of universal primers commonly used in molecular biology, such as: M13 (GTAAAACGACGGCCAGT), T3 (ATTAAC CCTCACTAAAG) or 7 (AATACGACTCACTATAG); 2 , a regular antisense microsatellite primer; and 3 , a fluorescently labeled primer, with the same sequence as the sense primer tail (Figure 1). The tails were tagged with either 6-FAM (M13 tail), HEX (T3 tail) or NED (T7 tail) (Life Technologies do Brasil Ltda., São Paulo, SP, Brazil).

PCR reactions $(20 \mu \mathrm{L})$ contained $30 \quad \mathrm{ng}$ DNA, PCR buffer $1 \mathrm{X}\left(10 \mathrm{mmol} \mathrm{L}^{-1}\right.$ Tris- $\mathrm{HCl}$, $\mathrm{pH} 8.8,50 \mathrm{mmol} \mathrm{L} \mathrm{L}^{-1} \mathrm{KCl}, 0.08 \% \mathrm{v} \mathrm{v}^{-1}$ Nonidet P40), $1.5 \mathrm{mmol} \mathrm{L}^{-1} \mathrm{MgCl}_{2}, 0.2 \mathrm{mmol} \mathrm{L^{-1 }} \mathrm{dNTP}$, $0.2 \mathrm{mmol} \mathrm{L}^{-1}$ of each primer (sense and antisense), and 1.0 U Taq DNA polymerase. For UTSP PCR reactions, the concentration of the tailed sense primer was five times lower $\left(0.04 \mathrm{mmol} \mathrm{L}^{-1}\right)$ than the other two primers. Reactions were carried out separately for each microsatellite locus. After optimization, 13 markers were selected based on their amplification profile, the smaller amount of stutter products, and the higher number of alleles (Table 1). All loci used were described by Cregan et al. (1999), except for AF162284 and Satt612, which were obtained from the integrated genetic linkage map constructed by Song et al. (2004). The amplification program consisted of an initial denaturation step at $94^{\circ} \mathrm{C}$ for $5 \mathrm{~min}$, followed by 35

Pesq. agropec. bras., Brasília, v.48, n.3, p.270-279, mar. 2013 DOI: 10.1590/S0100-204X2013000300005 
cycles with denaturation at $94^{\circ} \mathrm{C}$ for $40 \mathrm{~s}$, annealing at $50^{\circ} \mathrm{C}$ for $40 \mathrm{~s}$, and extension at $72^{\circ} \mathrm{C}$ for $40 \mathrm{~s}$. After the thirty-fifth cycle, a final extension step was performed at $72^{\circ} \mathrm{C}$, for $25 \mathrm{~min}$.

The cultivars were genotyped by both methods, i.e., conventional PCR evaluated in polyacrylamide gel and PCR with UTSP evaluated by capillary electrophoresis. The fluorescent genotyping (fragment size analysis) was performed in duplicate, on two different days (proof and counter proof). In the conventional method, PCR products were separated by electrophoresis in a $10 \%$ polyacrylamide gel, using $1 \mathrm{X}$ TBE buffer
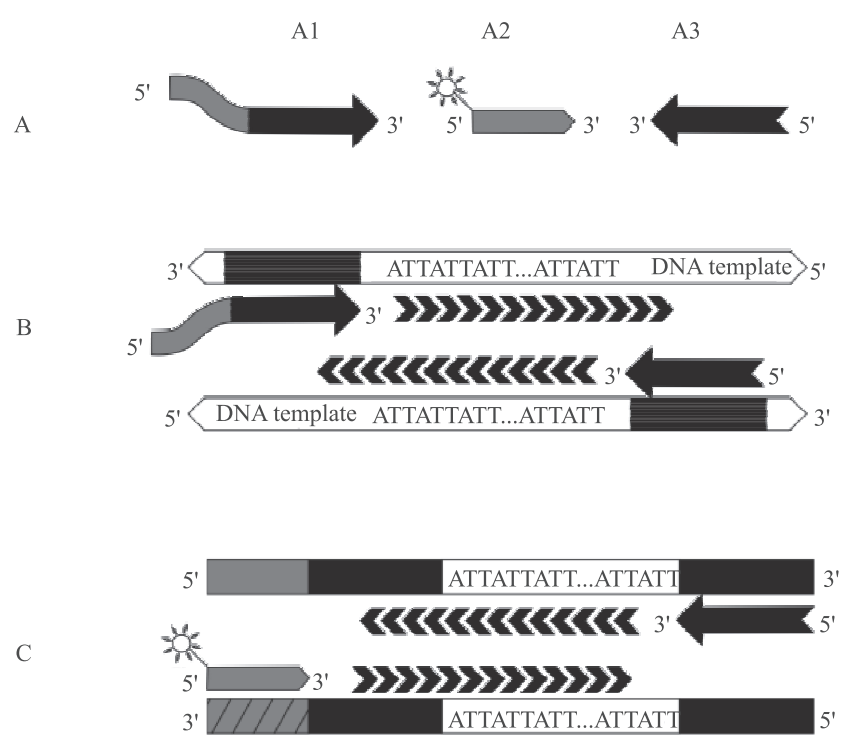

D

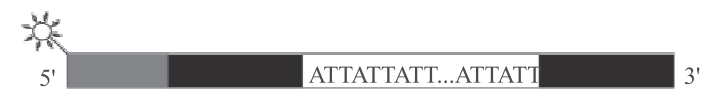

Figure 1. Universal tail sequence primers (UTSP) method: A, primers used for amplification of the fluorescent fragment, including a sense microsatellite primer with universal tail sequence (A1), a fluorescently labeled primer with the same universal tail sequence (A2), and an antisense microsatellite primer (A3); B, the first steps of the amplification cycle the specific regions of the genome complementary to the microsatellite primers are represented by black boxes; C, pairing of a fluorescently labeled primer to a complementary region (hatched gray box) synthesized in the early stages of PCR - the gray box represents the sequence of the tail incorporated to the amplicon due to annealing of the primer shown in B; and D, fluorescently labeled amplicons in the final stages of PCR.
(89 mmol L-1 Tris-borate, 2 mmol L-1 EDTA, $\mathrm{pH} 8.0$ ) for approximately 3 hours at $120 \mathrm{~V}$, and stained with ethidium bromide $\left(0.2 \mathrm{~g} \mathrm{~mL}^{-1}\right)$ for $10 \mathrm{~min}$. A vertical electrophoresis tank was used with a $15 \mathrm{~cm}$ dual glass plate, separated by $1.0 \mathrm{~mm}$ spacers, with a capacity of 60 samples per gel. The fragment sizes were estimated by comparison with a 50 bp DNA ladder (Promega, Madison, WI, USA). In the UTSP method, markers with distinct sizes and tagged with different fluorochromes were grouped in order to simultaneously detect by fluorescence the amplified alleles. The sample used for the electrophoretic analysis consisted of $0.4 \mu \mathrm{L}$ of the three independent PCR reactions, $8.55 \mu \mathrm{L}$ Hi-Di formamide, and $0.25 \mu \mathrm{L}$ ROX 500 molecular size standard. Capillary electrophoresis was performed in the ABI 3130xl equipment, according to the manufacturer's instructions (Life Technologies do Brasil Ltda., São Paulo, SP, Brazil). Data were automatically collected and coded using the software Gene Mapper 4.0 (Life Technologies do Brasil Ltda., São Paulo, SP, Brazil).

To check the effectiveness of the construction of the tailed sense microsatellite primer, a test was performed to compare the sizes (17 bp) of the products amplified by conventional PCR (sense primer with no tail) and by UTSP PCR. The PCR reactions were performed separately using cultivars BMX Magna RR and CD 202, which were analyzed in duplicate for four microsatellite loci (Satt233, Satt005, Sat_085, and Satt540) in both methods, and the electrophoresis was performed as described above for the conventional method, in $10 \%$ polyacrylamide gel (Figure 2). The polymorphic information content (PIC) was calculated for each marker according to the expression: $\mathrm{PIC}=1-\sum_{\mathrm{j}=1}^{\mathrm{n}} \mathrm{P}_{\mathrm{ij}}^{2}$, in which, $\mathrm{P}_{\mathrm{ij}}$ is the frequency of the $\mathrm{j}^{\text {th }}$ allele of the $\mathrm{i}^{\text {th }}$ marker (Anderson et al., 1993).

The probability of random identity was calculated as described by Schuster et al. (2009), according to the formula: $\prod_{i=1}^{n} P_{i}$, in which $P_{i}$ is the frequency of allele $A_{i}$, and $n$ is the number of the evaluated marker. For those eventually heterozygous loci, the frequencies used in the formula were that of the summed individual alleles.

The genetic relationships between genotypes were assessed by the complement of the similarity index for codominant and multiallelic variables from the 
unweighted index used to calculate the similarity matrix. The unweighted index is given by:

$\mathrm{S}_{\mathrm{ii}}=1 / 2 \mathrm{~L} \sum_{\mathrm{j}=1}^{\mathrm{L}} \mathrm{C}_{\mathrm{j}}$, in which $\mathrm{L}$ is the total number

of loci analyzed, and $\mathrm{C}_{\mathrm{j}}$ is the number of common alleles between cultivar pairs $i$ and i'.

The cophenetic correlation was obtained from the dissimilarity matrix, and cultivar clustering was performed by the unweighted pair group method with arithmetic mean (UPGMA). The correlation between the dissimilarity matrices obtained by the two genotyping methods was performed by the Mantel test with 10,000 simulations. The Genes software, version 2009, was used for these analyses (Cruz, 2006).

\section{Results and Discussion}

The expected difference of $17 \mathrm{bp}$ between the amplicons generated by the two genotyping methods was confirmed (Figure 2). The DNA bands obtained by the UTSP method were less intense; however, fewer unspecific bands were obtained by this method. This aspect can be easily observed in the amplification profiles obtained with the marker Sat_085.

The fragment sizes estimated for each marker in both genotyping methods for the 30 evaluated soybean cultivars are shown in Tables 2 and 3. Although the allele size obtained by the UTSP method was $17 \mathrm{bp}$ larger than the corresponding one genotyped by the conventional method, small differences could be observed between the sizes of some of the alleles when the two methods were compared. In the evaluated electrophoresis conditions, fragments differing by less than 4 bp had their identification hampered when genotyped by the conventional method in polyacrylamide gels.

For the UTSP genotyping method, the total number of alleles was 50, ranging from 2 (Satt045) to 7 (Satt005) per marker with an average of 3.85. The PIC ranged from 0.40 (Satt045) to 0.74 (Satt005), with an average of 0.62 . For the conventional method, the number of alleles was 38, ranging from 2 (Satt045, Satt070, and AF162283) to 5 (Satt005) alleles per marker, with an average of 2.92. The PIC ranged from 0.39 (Satt045) to 0.67 (Satt079), with an average of 0.56 (Tables 2 and 3 ). Several authors have used microsatellite markers to characterize soybean genotypes with different goals: wide genome genotyping (Sayama et al., 2011), genetic diversity for different traits (Mian et al., 2009; Singh et al., 2010), and germplasm characterization (Wang et al., 2008; Mulato et al., 2010). In these studies, the number of alleles per marker and PIC values ranged from 3 to 18 and from 0.507 to 0.815 , respectively. The results obtained in the present study are in accordance with those of Priolli et al. (2002), who characterized 186 Brazilian soybean genotypes using 12 SSR loci and detected an average of 5.3 alleles per locus and a mean PIC value of 0.64 .

The differences found between the two tested methods, regarding number of alleles and PIC values, can be explained by the greater accuracy of the UTSP

Table 1. Selected microsatellite primers for the analysis of soybean cultivars, using the conventional and the universal tail sequence primers (UTSP) methods.

\begin{tabular}{|c|c|c|c|c|}
\hline Marker & Sense primer $\left(5^{\prime} \rightarrow 3^{\prime}\right)^{(1)}$ & Antisense primer $\left(5^{\prime} \rightarrow 3^{\prime}\right)$ & Motif & LG \\
\hline AF162283/T3 & ATTAACCCTCACTAAAG GCGAGTTCTGGATGTAGG & GCGTGGCGGCTTTGGTAG & $(\mathrm{CT})_{11}$ & G \\
\hline GMABAB/T3 & ATTAACССТCACTAAAG CAAAACATAAAAAAGGTGAGA & AAGAACCACACTAATATTATT & $(\mathrm{ATT})_{25}$ & N1 \\
\hline Satt002/T7 & AATACGACTCACTATAG TGTGGGTAAAATAGATAAAAAT & TCATTTTGAATCGTTGAA & $(\mathrm{ATT})_{25}$ & $\mathrm{D} 2$ \\
\hline att005/T7 & AATACGACTCACTATAG TATCCTAGAGAAGAACTAAAAAA & GTCGATTAGGCTTGAAATA & $(\mathrm{ATT})_{19}$ & $\mathrm{D} 1 \mathrm{~b}$ \\
\hline Satt045/T7 & AATACGACTCACTATAG TGGTTTCTACTTTCTATAATTATTT & ATGCCTCTCCСТCCT & $(\mathrm{ATT})_{18}$ & $\mathrm{E}$ \\
\hline att070/M13 & GTAAAACGACGGCCAG TTAAAAATTAAAATACTAGAAGACAAC & TGGCATTAGAAAATGATATG & $(\mathrm{ATT})_{24}$ & B2 \\
\hline Satt079/T3 & ATTAACCCTCACTAAAG AGTCGAAGATACACAATTAGAT & CTTTTAGACACAAATTTATCACT & $(\mathrm{ATT})_{13}$ & $\mathrm{C} 2$ \\
\hline Sat_085/T3 & ATTAACCCTCACTAAAG GGTTTTAGATCCTTAAATTTGT & GGGGAAGCAAGTAGCT & $(\mathrm{AT})_{23}$ & $\mathrm{C} 1$ \\
\hline Satt114/T3 & ATTAACCCTCACTAAAG GGGTTATCCTCCCCAATA & ATATGGGATGATAAGGTGAA & $(\mathrm{ATT})_{17}$ & $\mathrm{~F}$ \\
\hline Satt233/M13 & GTAAAACGACGGCCAG TAAGCATACTCGTCGTAAC & GCGGTGCAAAGATATTAGAAA & $(\mathrm{ATT})_{16}$ & A2 \\
\hline Satt431/T7 & AATACGACTCACTATAG GCGTGGCACCCTTGATAAATAA & GCGCACGAAAGTTTTTCTGTAACA & $(\mathrm{ATT})_{21}$ & $\mathrm{~J}$ \\
\hline Satt540/M13 & GTAAAACGACGGCCAG TCTGGCGAATCAAGCTTTGTAAC & CCGTGATTGCGAAGAGGATATT & $(\mathrm{ATT})_{12}$ & M \\
\hline Satt612/T7 & AATACGACTCACTATAG GTCATACTGGGTGTTTCATTTATGAC & GCGCCTTTTAGTCTCTGAAAGTATTT & $(\mathrm{ATT})_{10}$ & G \\
\hline
\end{tabular}

${ }^{(1)}$ The sequence highlighted in black was included in the sense primers used in the UTSP method. LG, linkage group. 
method, which uses an automatic DNA sequencer, as opposed to gel electrophoresis in the conventional method (Wenz et al., 1998). These differences can be overcome if longer polyacrylamide gel is used under denaturing conditions (Sánches-Pérez et al., 2006). At least two extra alleles could be detected for markers Satt005, GMABAB, and AF162283, using the UTSP method. Amplification artifacts may also have influenced the number of alleles detected by either method. It is a well-known fact that Taq DNA polymerase adds an extra nucleotide (usually adenosine) to the 3' end of the newly synthesized fragment. This modification may affect the precise determination of the fragment size (Pompanon et al., 2005). A larger extension time (more than $20 \mathrm{~min}$ ) after the final PCR cycle increases the chance of all fragments being adenylated, minimizing the effect of the extra nucleotide on fragment size determination, therefore, the final extension time was increased in both genotyping methods.

Another common artifact that can influence data interpretation is the stutter, which is explained by the "slippage" of DNA polymerase during DNA synthesis, producing fragments sizes similar to the real size of the allele (Hauge \& Litt, 1993). The stutter can overlay heterozygote alleles and interfere with the interpretation of the generated amplification profile (Miller \& Yuan, 1997). Higher precision in the detection of alleles can be obtained under electrophoretic systems with high resolution capabilities. This explains why a higher number of heterozygotes could be detected in the UTSP method. An important parameter to be considered for cultivar identification is the probability of random identity (PRI), which corresponds to the probability that an individual taken at random and analyzed with a specific set of markers will be equal to any other individual in the population (Schuster et al., 2009). PRI is calculated by the product of individual allele frequencies at each locus. In the case of the UTSP method, PRI varied from $1.41 \times 10^{-8}$ (CD 240RR) to $9.54 \times 10^{-6}$ (BRS 184), whereas for the conventional method, PRI varied from $1.12 \times 10^{-6}$ (BRS Pampa RR) to $8.45 \times 10^{-5}$ (CD 219RR). These numbers indicate that

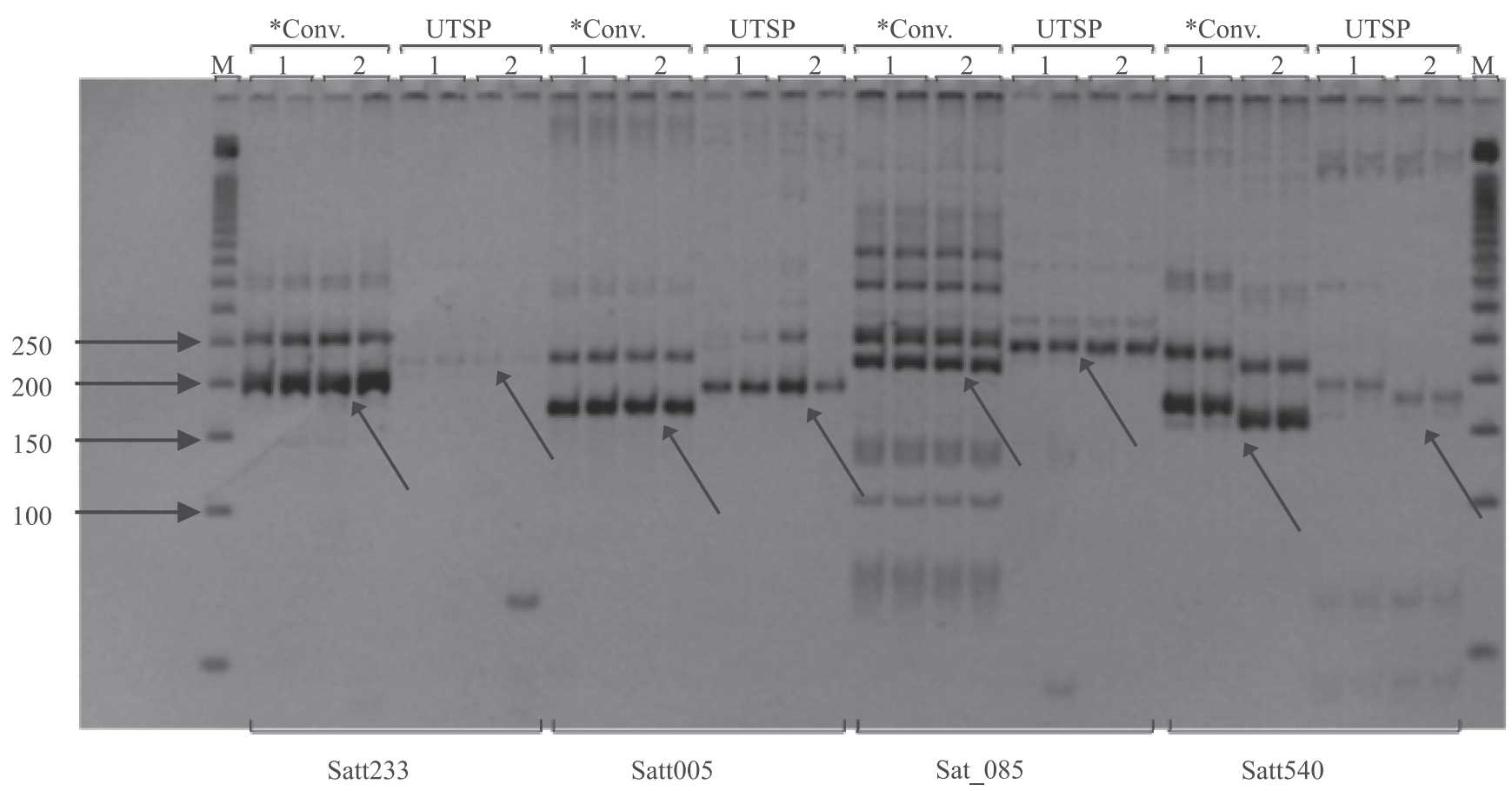

Figure 2. Comparison between the amplification profiles obtained with the conventional (*Conv.) method and with the universal tail sequence primers (UTSP) method. The markers are identified at the bottom portion of the figure. Cultivar BMX Magna RR is indicated by number 1, and CD 202, by number 2. "M" indicates a 50 bp DNA ladder. Analyses were done in duplicate. The sizes of the DNA ladder fragments (bp) are indicated by arrows on the left side of the figure. The other arrows indicate the specific amplification product for each marker. 
the discriminating power of the UTSP method, for this population, can be as high as one order of magnitude greater than that of the conventional method.

Despite the differences between the two genotyping methods, the correlation between the dissimilarity matrices obtained by them (0.8026) was significant at $1 \%$ probability by the Mantel test and the test $\left(p=9.99 \times 10^{-5}\right)$. Values for cophenetic correlation, distortion, and stress were $0.74,2.35 \%$, and $15.33 \%$ with the UTSP method, and $0.71,3.04 \%$, and $17.44 \%$ with the conventional method. The higher cophenetic correlation and the lower values of distortion and stress obtained for the UTSP method indicate that the graphic representation of genetic distances will better fit the original distance matrix.
The obtained dendrograms were also compared and evaluated as to the formation of genotype groups (Figure 3). With the set of 13 markers used, all genotypes could be distinguished, even those closely related genetically, showing the high discrimination power of this set of markers. It has already been shown that the distinction of soybean cultivars is extremely difficult due to their narrow genetic base, especially between essentially derived cultivars (Rodrigues et al., 2008).

The groups formed by the two methods were highly similar and coherent with their pedigree and phenotypic data used for varietal registration. For instance, cultivars MG/BR 46 Conquista, BRS Valiosa RR, and BRSMG 850GRR were grouped together

Table 2. Estimated size of amplified fragments, number of alleles, and polymorphic information content (PIC) in 30 soybean cultivars for the AF162283, GMABAB, Sat_085, Satt002, Satt005, Satt045, and Satt070 markers, using the universal tail sequence primers (UTSP) and the conventional methods.

\begin{tabular}{|c|c|c|c|c|c|c|c|c|c|c|c|c|c|c|}
\hline \multirow[t]{2}{*}{ Cultivar } & \multicolumn{2}{|c|}{ AF162283 } & \multicolumn{2}{|c|}{ GMABAB } & \multicolumn{2}{|c|}{ Sat_085 } & \multicolumn{2}{|c|}{ Satt002 } & \multicolumn{2}{|c|}{ Satt005 } & \multicolumn{2}{|c|}{ Satt045 } & \multicolumn{2}{|c|}{ Satt070 } \\
\hline & UTSP & Conv. & UTSP & Conv. & UTSP & Conv. & UTSP & Conv. & UTSP & Conv. & UTSP & Conv. & UTSP & Conv. \\
\hline BMX Magna RR & 249 & 230 & 187 & 170 & 221 & 205 & 148 & 140 & 177 & 165 & 151 & 140 & 165 & 150 \\
\hline BRS 133 & 241 & 220 & 166 & 150 & 229 & 215 & 142 & 135 & 198 & 190 & 157 & 145 & 165 & 150 \\
\hline BRS 184 & 241 & 220 & 178 & 160 & 219 & 205 & $142 / 148$ & 135 & 174 & 165 & 157 & 145 & 165 & 150 \\
\hline BRS 213 & 249 & 230 & 166 & 150 & 191 & 180 & 148 & 140 & $174 / 177$ & 165 & 151 & 140 & $165 / 189$ & $150 / 175$ \\
\hline BRS 214 & 249 & 230 & 166 & 150 & 221 & 205 & 154 & 145 & 177 & 165 & 151 & 140 & 192 & 175 \\
\hline BRS 255RR & 249 & 230 & 166 & 150 & 219 & 205 & $148 / 154$ & 135 & 201 & 190 & 151 & 140 & $165 / 189$ & $150 / 175$ \\
\hline BRS 256RR & 241 & 220 & 166 & 150 & 219 & 205 & $142 / 154$ & 135 & 174 & 165 & 157 & 145 & 165 & 150 \\
\hline BRS 262 & 241 & 220 & 166 & 150 & 191 & 180 & 142 & 135 & 177 & 165 & 151 & 140 & 192 & 175 \\
\hline BRS 270RR & 247 & 230 & 178 & 160 & 191 & 180 & 142 & 135 & 177 & 165 & 151 & 140 & 192 & 175 \\
\hline BRS Charrua RR & 241 & 220 & 166 & 150 & 229 & 215 & 142 & 135 & 198 & 190 & $-(1)$ & 145 & 165 & 150 \\
\hline BRS Gisele RR & 241 & 220 & 178 & 160 & 219 & 205 & 154 & 145 & 174 & 165 & 151 & 140 & 165 & 150 \\
\hline BRSMG 850GRR & 241 & 220 & 178 & 160 & 219 & 205 & 154 & - & 165 & 155 & $151 / 157$ & 140 & 165 & 150 \\
\hline BRS Pampa RR & 241 & 220 & 166 & 150 & 229 & 215 & 142 & 135 & 198 & 190 & 157 & 145 & 165 & 150 \\
\hline BRSMT Pintado & 249 & 230 & 166 & 150 & 191 & 180 & 148 & - & 177 & 165 & 151 & 140 & 192 & 175 \\
\hline BRS Valiosa RR & 241 & 220 & 178 & 160 & 219 & 205 & 154 & 145 & 165 & 155 & $151 / 157$ & 140 & 165 & 150 \\
\hline CD 202 & 245 & 230 & 175 & 160 & 219 & 205 & 142 & 135 & 177 & 165 & 151 & 140 & 165 & 150 \\
\hline CD 206 & 249 & 230 & 175 & 160 & 219 & 205 & 142 & 135 & 198 & 190 & 151 & 140 & 165 & 150 \\
\hline CD 213RR & 241 & 220 & 178 & 160 & 221 & 205 & 142 & 135 & 177 & 165 & 157 & 145 & 165 & 150 \\
\hline CD 214RR & 249 & 230 & 178 & 160 & 221 & 205 & 142 & 135 & 177 & 165 & 151 & 140 & 189 & 175 \\
\hline CD 215 & 245 & 220 & 178 & 160 & 219 & 205 & 142 & 135 & 177 & 165 & 151 & 140 & 165 & 150 \\
\hline CD 217 & 241 & 220 & 178 & - & 191 & 180 & 148 & 140 & 165 & 155 & 151 & 140 & 189 & 175 \\
\hline CD 219RR & 247 & 230 & 178 & 160 & 191 & 180 & 142 & 135 & 174 & 165 & 151 & 140 & 189 & 175 \\
\hline CD 226 & 245 & 230 & 166 & 150 & 191 & 180 & 148 & 140 & 177 & 165 & 151 & 140 & 189 & 175 \\
\hline CD 228 & 247 & 230 & 182 & 170 & $191 / 219$ & 180 & 142 & - & 174 & 165 & 151 & 140 & $165 / 192$ & $150 / 175$ \\
\hline CD 229RR & 247 & 230 & 166 & 150 & 191 & 180 & 142 & - & 156 & 145 & 151 & 140 & 165 & 150 \\
\hline CD 237RR & 241 & 220 & 178 & 160 & 191 & 180 & 148 & - & 177 & 165 & 151 & 140 & 189 & 175 \\
\hline CD 240RR & 245 & 230 & 178 & 160 & - & 205 & 142 & - & 177 & 165 & 157 & 145 & 165 & 150 \\
\hline MG/BR 46 Conquista & 241 & 220 & 178 & 160 & 219 & 205 & 154 & 145 & 165 & 155 & 151 & 140 & 165 & 150 \\
\hline M-SOY 7501 & 241 & 220 & 178 & 160 & 219 & 205 & 148 & 140 & $183 / 198$ & 170 & 157 & 145 & 189 & 175 \\
\hline Vmax & 249 & 230 & 166 & 150 & 219 & 205 & 142 & 135 & 165 & 155 & 151 & 140 & 165 & 150 \\
\hline Number of alleles & 4 & 2 & 5 & 3 & 4 & 3 & 3 & 3 & 7 & 5 & 2 & 2 & 3 & 2 \\
\hline PIC & 0.68 & 0.50 & 0.62 & 0.56 & 0.69 & 0.56 & 0.58 & 0.54 & 0.74 & 0.58 & 0.40 & 0.39 & 0.54 & 0.47 \\
\hline
\end{tabular}

${ }^{(1)}$ Missing datum. 
(Figure 3). Cultivar BRS Valiosa RR is essentially derived from cultivar MG/BR 46 Conquista. It was obtained after five backcross cycles, but it harbors a gene conferring resistance to glyphosate. Cultivar BRSMG 850 GRR was protected and declared by its holders as being highly similar to BRS Valiosa RR. Two other cultivars that were grouped together were CD 215RR and CD 202. Cultivar CD 215RR was protected and declared as highly similar to CD 202. A third example refers to cultivars CD 237RR and CD 217, which were grouped together. CD 237RR is essentially derived from cultivar CD 217. However, grouping of cultivars BRS Pampa RR, BRS 133, and BRS Charrua RR by both genotyping methods was slightly discrepant. These three cultivars were grouped together by the UTSP method, but cultivar BRS Pampa RR was grouped separately by the conventional method. BRS Pampa RR was obtained from the triple cross between Embrapa 61, E96-246, and BRS 133, followed by backcrossing to BRS 133 . BRS Charrua RR was protected as being highly similar to BRS 133.

The use of microsatellite marker data for distinguishing soybean cultivars showed high similarity with pedigree information. This is a strong indication that microsatellite marker information can be used as a complementary tool, associated to morphological descriptors, for germplasm classification and intellectual property protection.

Table 3. Estimated size of amplified fragments, number of alleles, and polymorphic information content (PIC) in 30 soybean cultivars for the Satt079, Satt114, Satt233, Satt431, Satt540, and Satt612 markers, using the universal tail sequence primers (UTSP) and the conventional methods.

\begin{tabular}{|c|c|c|c|c|c|c|c|c|c|c|c|c|}
\hline \multirow[t]{2}{*}{ Cultivar } & \multicolumn{2}{|c|}{ Satt079 } & \multicolumn{2}{|c|}{ Satt114 } & \multicolumn{2}{|c|}{ Satt233 } & \multicolumn{2}{|c|}{ Satt431 } & \multicolumn{2}{|c|}{ Satt540 } & \multicolumn{2}{|c|}{ Satt612 } \\
\hline & UTSP & Conv. & UTSP & Conv. & UTSP & Conv. & UTSP & Conv. & UTSP & Conv. & UTSP & Conv. \\
\hline BMX Magna RR & 166 & $-(1)$ & 121 & 110 & 217 & 200 & 251 & 240 & 183 & 170 & 256 & 245 \\
\hline BRS 133 & 142 & 130 & 109 & 100 & 205 & 185 & 251 & 240 & 186 & 170 & 256 & 245 \\
\hline BRS 184 & 160 & 145 & 109 & 100 & 205 & 185 & 251 & 240 & 186 & 170 & 256 & 245 \\
\hline BRS 213 & 166 & 150 & 109 & 100 & $217 / 226$ & $200 / 205$ & 206 & 190 & 165 & 150 & 256 & 245 \\
\hline BRS 214 & 166 & 150 & 109 & 100 & 217 & 200 & 251 & 240 & 171 & 160 & 256 & 245 \\
\hline BRS 255RR & 166 & - & 94 & 80 & $205 / 226$ & $185 / 205$ & 218 & 210 & 165 & 150 & 256 & 245 \\
\hline BRS 256RR & 160 & 145 & 94 & 80 & 226 & 205 & $206 / 218$ & 210 & 186 & 170 & 256 & 245 \\
\hline BRS 262 & 142 & 130 & 109 & 100 & 217 & 200 & 251 & 240 & 183 & 170 & 256 & 245 \\
\hline BRS 270RR & 166 & 150 & 109 & 100 & 205 & 185 & $194 / 206$ & $190 / 240$ & 183 & 170 & 250 & 240 \\
\hline BRS Charrua RR & 160 & 145 & 109 & 100 & 205 & 185 & 251 & 240 & 171 & 170 & $250 / 256$ & 245 \\
\hline BRS Gisele RR & 160 & 145 & 94 & 80 & 205 & 185 & $206 / 218$ & $210 / 240$ & 171 & 160 & 250 & 240 \\
\hline BRSMG 850GRR & 160 & 145 & 94 & 80 & $205 / 226$ & $185 / 205$ & 218 & 210 & 171 & 160 & 256 & 245 \\
\hline BRS Pampa RR & 142 & 130 & 109 & 100 & 217 & 200 & $206 / 251$ & $190 / 240$ & 165 & 150 & 250 & 240 \\
\hline BRSMT Pintado & 166 & 150 & 109 & 100 & 205 & 185 & 251 & 240 & 183 & - & 256 & 245 \\
\hline BRS Valiosa RR & 160 & 145 & 94 & 80 & 205 & 185 & 218 & 210 & 171 & 160 & 256 & 245 \\
\hline CD 202 & 142 & 130 & 118 & 110 & 217 & 200 & 218 & 210 & 171 & 160 & 265 & 250 \\
\hline CD 206 & 160 & 145 & 94 & 80 & 205 & 185 & 251 & 240 & 186 & 170 & 256 & 245 \\
\hline CD 213RR & 166 & 150 & 109 & 100 & $205 / 226$ & $185 / 205$ & $206 / 251$ & $190 / 240$ & 165 & 150 & 250 & 240 \\
\hline CD 214RR & 166 & 150 & 121 & 110 & 217 & 200 & $206 / 218$ & $190 / 210$ & 183 & 170 & 256 & 245 \\
\hline CD 215 & 142 & 130 & 109 & 100 & 217 & 200 & 251 & 240 & 171 & 160 & 265 & 250 \\
\hline CD 217 & 142 & 130 & 94 & 80 & 217 & 200 & 251 & 240 & 183 & - & 256 & 245 \\
\hline CD 219RR & - & 130 & 109 & 100 & 217 & 200 & 251 & 240 & 186 & - & 250 & 240 \\
\hline CD 226 & 166 & 150 & 109 & 100 & $217 / 226$ & 200 & $194 / 206$ & 190 & 165 & 150 & 265 & 250 \\
\hline CD 228 & 163 & 150 & 121 & 110 & 205 & 185 & 251 & 240 & 171 & - & 250 & 240 \\
\hline CD 229RR & 142 & 130 & 94 & 80 & 205 & 185 & 251 & 240 & 171 & 160 & 250 & 240 \\
\hline CD 237RR & 142 & 130 & 94 & 80 & 217 & 200 & 251 & 240 & 183 & - & 256 & 245 \\
\hline CD 240RR & 163 & 150 & 118 & 110 & 217 & 200 & 218 & 210 & 171 & - & 265 & 250 \\
\hline MG/BR 46 Conquista & 160 & 145 & 94 & 80 & 205 & 185 & 218 & 210 & 171 & 150 & 256 & 245 \\
\hline M-SOY 7501 & 160 & 145 & 109 & 100 & 217 & 200 & 251 & $210 / 240$ & 186 & - & 256 & 245 \\
\hline Vmax & 166 & 150 & 121 & 110 & 217 & 200 & 251 & 210 & 171 & - & 265 & 250 \\
\hline Number of alleles & 4 & 3 & 4 & 3 & 3 & 3 & 4 & 3 & 4 & 3 & 3 & 3 \\
\hline PIC & 0.70 & 0.67 & 0.65 & 0.63 & 0.60 & 0.58 & 0.59 & 0.58 & 0.72 & 0.66 & 0.57 & 0.56 \\
\hline
\end{tabular}

${ }^{(1)}$ Missing datum. 
$\mathrm{A}$

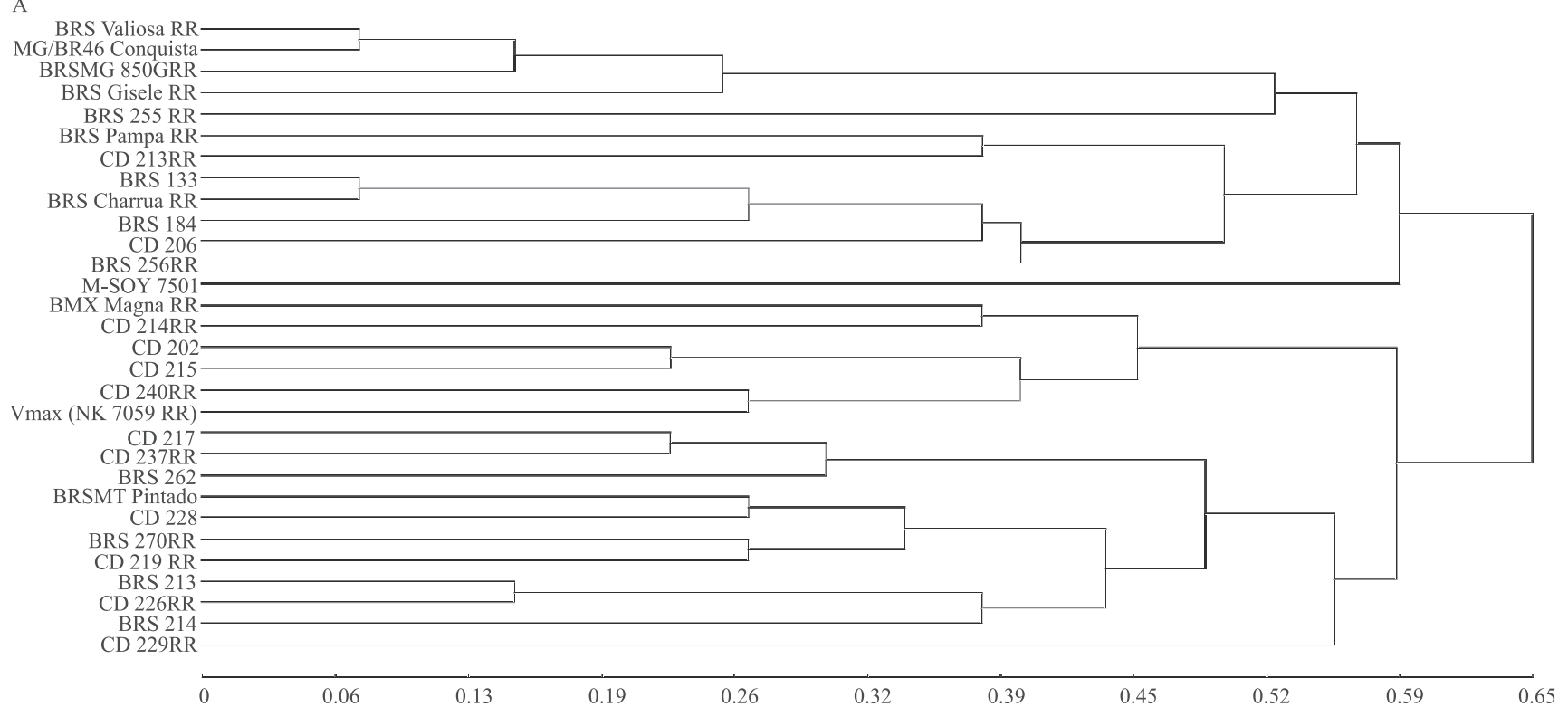

B

BRS Valiosa RR

MG/BR46 Conquista

BRSMG 850GRR

BRS Gisele RR

BRS 255 RR

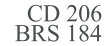

M-SOY 7501 BRS 256RR BRS 133

BRS Pampa RR
BRS Charrua RR

CD 213RR

CD 202

CD 240RR

Vmax (NK 7059 RR)

CD 228

CD 229RR

BRS 270RR

CD 219RR

CD 226RR

CD 217

CD 237RR
BMX Magna RR
CD 214RR

CD 214RR

BRS MT Pintado

BRS 214

0

0.07

0.14

0.21

0.28

$0.35 \quad 0.42$

$0.42 \quad 0.49$

0.56

0.63

0.7

Figure 3. Clustering of 30 soybean cultivars obtained with: A, the conventional genotyping method; and B, the universal tails sequence primers (UTSP) genotyping method. Genotyping was done with 13 microsatellites, and clustering with the unweighted pair group method with arithmetic mean (UPGMA).

\section{Conclusions}

1. The universal tail sequence primers (UTSP) method is very effective to detect polymorphisms among soybean cultivars, when compared to the conventional genotyping method using polyacrylamide gels.

2. The low cost of the UTSP method associated with its high accuracy, possibility for automation, and high throughput analysis makes it ideal for the characterization of soybean cultivars and for the determination of genetic purity.

3. A highly robust and informative set of SSR markers is presented here, which can be used for diversity analysis and for identification of soybean cultivars. 


\section{Acknowledgements}

To the Agência Brasileira de Inovação (Finep) for financial support; and to AgroGenética, for providing a sound infrastructure for carrying out the research.

\section{References}

ANDERSON, J.A.; CHURCHILL, G.A.; AUTRIQUE, J.E.; TANKSLEY, S.D.; SORRELLS M.E. Optimizing parental selection for genetic linkage maps. Genome, v.36, p.181-186, 1993. DOI: $10.1139 / \mathrm{g} 93-024$.

ARRUDA, M.P. de; GONÇALVES, E.C.; SCHNEIDER, M.P.C.; SILVA, A.L.C.; MORIELLE-VERSUTE, E. An alternative genotyping method using dye-labeled universal primer to reduce unspecific amplifications. Molecular Biology Reports, v.37, p.2031-2036, 2010. DOI: 10.1007/s11033-009-9655-7.

BRASIL. Ministério da Agricultura, Pecuária e Abastecimento. Serviço Nacional de proteção de cultivar. CultivarWeb. 2013. Disponível em: <http://extranet.agricultura.gov.br/php/snpc/ cultivarweb/cultivares protegidas.php>. Acesso em: 9 mar. 2013.

COMPANHIA NACIONAL DE ABASETECIMENTO. Acompanhamento da safra 2012/2013. 2013. Disponível em: $<$ http://www.conab.gov.br>. Acesso em: 8 mar. 2013.

CREGAN, P.B.; JARVIK, T.; BUSH, A.L.; SHOEMAKER, R.C.; LARK, K.G.; KAHLER, A.L.; KAYA, N.; VANTOAI, T.T.; LOHNES, D.G.; CHUNG, J.; SPECHT, J.E. An integrated genetic linkage map of the soybean genome. Crop Science, v.39, p.1464-1490, 1999. DOI: 10.2135/cropsci1999.3951464x.

CRUZ, C.D. Programa GENES: versão Windows: aplicativo computacional em genética e estatística. Viçosa: UFV, 2006. 648p.

DINIZ, F.M.; IYENGAR, A.; LIMA, P.S. da C.; MACLEAN, N.; BENTZEN, P. Application of a double-enrichment procedure for microsatellite isolation and the use of tailed primers for high throughput genotyping. Genetics and Molecular Biology, v.30, p.380-384, 2007. DOI: 10.1590/S1415-47572007000300014.

DIWAN, N.; CREGAN, P.B. Automated sizing of fluorescent labeled simple sequence repeat (SSR) markers to assay genetic variation in soybean. Theoretical and Applied Genetics, v.95, p.723-733, 1997. DOI: 10.1007/s001220050618.

GARCIA, A.F.; ALBERINI, J.L.; ZUCCHI, M.I.; SOUZA, A.P. de. Microsatellite molecular markers in the cultivar identification of Brazilian soybean for human consumption. Crop Breeding and Applied Biotechnology, v.7, p.155-164, 2007.

GOULART, I.C.G. dos R.; MEROTTO JUNIOR, A.; NUNES, A.L.; BERED, F. Otimização da utilização de marcadores moleculares microssatélites e sua aplicação em estudos com plantas daninhas. Planta Daninha, v.29, p.1175-1181, 2011. DOI: $10.1590 / \mathrm{S} 0100-83582011000500025$.

HAUGE X.Y.; LITT, M. A study of the origin of 'shadow bands' seen when typing dinucleotide repeat polymorphisms by the PCR. Human Molecular Genetics, v.4, p.411-415, 1993. DOI: 10.1093/ $\mathrm{hmg} / 2.4 .411$.
HAYDEN, M.J.; NGUYEN, T.M.; WATERMAN, A.; CHALMERS, K.J. Multiplex-ready PCR: a new method for multiplexed SSR and SNP genotyping. BMC Genomics, v.9, 2008. DOI: $10.1186 / 1471-2164-9-80$.

KALIA, R.K.; RAI, M.K.; KALIA, S.; SINGH, R.; DHAWAN, A.K. Microsatellite markers: an overview of the recent progress in plants. Euphytica, v.177, p.309-334, 2011. DOI: 10.1007/ s10681-010-0286-9.

LAZARUK, K.; WALSH, P.S.; OAKS, F.; GILBERT, D.; ROSENBLUM, B.B.; MENCHEN, S.; SCHEIBLER, D.; WENZ, H.M.; HOLT, C.; WALLIN, J. Genotyping of forensic short tandem repeat (STR) systems based on sizing precision in a capillary electrophoresis instrument. Electrophoresis, v.19, p.86-93, 1998. DOI: $10.1002 /$ elps.1150190116.

MARCELINO, F.C.; GUIMARÃES, M.F.M.; BARROS, E.G. de. Detection and quantification of Roundup Ready (R) soybean residues in sausage samples by conventional and real-time PCR. Ciência e Tecnologia de Alimentos, v.28, p38-45, 2008. DOI: 10.1590/S0101-20612008000500007.

MIAN, M.A.R.; KANG, S.-T.; REDINBAUGH, M.G. Microsatellite diversity of soybean genotypes differing in bean pod mottle virus leaf symptom. Canadian Journal of Plant Science, v.89, p.359-367, 2009. DOI: 10.4141/CJPS08046.

MILLER, M.J.; YUAN, B.Z. Semiautomated resolution of overlapping stutter patterns in genomic microsatellite analysis. Analytical Biochemistry, v.251, p.50-56, 1997. DOI: 10.1006/ abio.1997.2234.

MISSIAGGIA, A.; GRATTAPAGLIA, D. Plant microsatellite genotyping with 4-color fluorescent detection using multiple-tailed primers. Genetics and Molecular Research, v.5, p.72-78, 2006.

MULATO, B.M.; MÖLLER, M.; ZUCCHI, M.I.; QUECINI, V.; PINHEIRO, J.B. Genetic diversity in soybean germplasm identified by SSR and EST-SSR markers. Pesquisa Agropecuária Brasileira, v.45, p.276-283, 2010. DOI: 10.1590/S0100204X2010000300007.

OBLESSUC, P.R.; CAMPOS, T. de; CARDOSO, J.M.K.; SFORÇA, D.A.; BARONI, R.M.; SOUZA, A.P.; BENCHIMOL, L.L. Adaptation of fluorescent technique for genotyping with new microsatellite markers in common bean. Pesquisa Agropecuária Brasileira, v.44, p.638-644, 2009. DOI: 10.1590/S0100-204X2009000600013.

OETTING, W.S.; LEE, H.K.; FLANDERS, D.J.; WIESNER, G.L.; SELERS, T.A.; KING, R.A. Linkage analysis with multiplexed short tandem repeat polymorphisms using infrared fluorescence and M13 tailed primers. Genomics, v.30, p.450-458, 1995. DOI: 10.1006/geno.1995.1264.

OLIVEIRA, M.B.; VIEIRA, E.S.N.; SCHUSTER, I. Construction of a molecular database for soybean cultivar identification in Brazil. Genetics and Molecular Research, v.9, p.705-720, 2010. DOI: $10.4238 /$ vol9-2gmr706.

POMPANON, F.; BONIN, A.; BELLEMAIN, E.; TABERLET, P. Genotyping errors: causes, consequences, and solutions. Nature Reviews Genetics, v.6, p.847-859, 2005. DOI: 10.1038/nrg1707. 
PRIOLLI, R.H.G.; MENDES-JUNIOR, C.T.; ARANTES, N.E.; CONTEL, E.P.B. Characterization of Brazilian soybean cultivars using microsatellite markers. Genetics and Molecular Biology, v.25, p.185-193, 2002. DOI: 10.1590/S1415-47572002000200012.

PRIOLLI, R.H.G.; MENDES-JUNIOR, C.T.; SOUSA, S.M.B.; SOUSA, N.E.A.; CONTEL, E.P.B. Diversidade genética da soja entre períodos e entre programas de melhoramento no Brasil. Pesquisa Agropecuária Brasileira, v.39, p.967-975, 2004. DOI: 10.1590/S0100-204X2004001000004.

PRIOLLI, R.H.G.; PINHEIRO, J.B.; ZUCCHI, M.I.; BAJAY, M.M.; VELLO, N.A. Genetic diversity among Brazilian soybean cultivars base on SSR loci and pedigree data. Brazilian Archives of Biology and Technology, v.53, p.519-531, 2010. DOI: 10.1590/ S1516-89132010000300004.

RODRIGUES, D.H.; ALCÂNTARA NETO, F. de; SCHUSTER, I. Identification of essentially derived soybean cultivars using microsatellite markers. Crop Breeding and Applied Biotechnology, v.8, p.74-78, 2008.

SÁNCHEZ-PÉREZ, R.; BALLESTER, J.; DICENTA, F.; ARÚS, P.; MARTÍNEZ-GÓMEZ, P. Comparison of SSR polymorphisms using automated capillary sequencers, and polyacrylamide and agarose gel electrophoresis: implications for the assessment of genetic diversity and relatedness in almond. Scientia Horticulturae, v.108, p.310-316, 2006. DOI: 10.1016/j.scienta.2006.02.004.

SAYAMA, T.; HWANG, T.Y.; KOMATSU, K.; TAKADA, Y.; TAKAHASHI, M.; KATO, S.; SASAMA, H.; HIGASHI, A.; NAKAMOTO, Y.; FUNATSUKI, H.; ISHIMOTO, M. Development and application of a whole-genome simple sequence repeat panel for high-throughput genotyping in soybean. DNA Research, v.18, p.107-115, 2011. DOI: 10.1093/dnares/dsr003.
SCHUSTER, I.; QUEIROZ, V.T. de; TEIXEIRA, A.I.; BARROS, E.G. de; MOREIRA, M.A. Determinação da pureza varietal de sementes de soja com o auxílio de marcadores moleculares microssatélites. Pesquisa Agropecuária Brasileira, v.39, p.247-253, 2004. DOI: 10.1590/S0100-204X2004000300007.

SCHUSTER, I.; VIEIRA, E.S.N.; PADILHA, L. Marcadores moleculares no pós-melhoramento. In: BÓREM, A.; CAIXETA, E.T. (Ed.). Marcadores moleculares. 2.ed. Viçosa: 2009. p.177-208.

SINGH, R.K.; BHATIA, V.S.; BHAT, K.V.; MOHAPATRA, T.; SINGH, N.K.; BANSAL, K.C.; KOUNDAL, K.R. SSR and AFLP based genetic diversity of soybean germplasm differing in photoperiod sensitivity. Genetics and Molecular Biology, v.33, p.319-324, 2010. DOI: 10.1590/S1415-47572010005000024.

SONG, Q.J.; MAREK, L.F.; SHOEMAKER, R.C.; LARK, K.G.; CONCIBIDO, V.C.; DELANNAY, X.; SPECHT, J.E.; CREGAN, P.B. A new integrated genetic linkage map of the soybean. Theoretical and Applied Genetics, v.109, p.122-128, 2004. DOI: 10.1007/s00122-004-1602-3.

WANG, L.X.; GUAN, R.X.; LI, Y.H.; LIN, F.Y.; LUAN, W.J.; LI, W.; MA, Y.S.; LIU, Z.X.; CHANG, R.Z.; QIU, L.J. Genetic diversity of Chinese spring soybean germplasm revealed by SSR markers. Plant Breeding, v.127, p.56-61, 2008. DOI: j.14390523.2007.01429.x.

WENZ, H.M.; ROBERTSON, J.M.; MENCHEN, S.; OAKS, F.; DEMOREST, D.M.; SCHEIBLER, D.; ROSENBLUM, B.B.; WIKE, C.; GILBERT, D.A.; EFCAVITCH J.W. High-precision genotyping by denaturing capillary electrophoresis. Genome Research, v.8, p.69-80, 1998.

$\overline{\text { Received on May 10, } 2012 \text { and accepted on February 28, } 2013}$ 